\title{
Effect of Pre-harvest Spray of Nutrients and Growth Regulators on Quality Parameters of Sapota under Hill Zone of Karnataka, India
}

\author{
Vani Kumbar $^{1}$ *, B.S. Shivakumar ${ }^{1}$, M. Ganapathi ${ }^{2}$, Y. Kantharaj ${ }^{3}$ and H.S. Chaitanya ${ }^{4}$ \\ ${ }^{1}$ Department of Fruit Science, ${ }^{2}$ Department of Crop Physiology, ${ }^{3}$ Department of Post-Harvest \\ Technology, $\mathrm{COH}$, Mudigere, India \\ ${ }^{4}$ Horticulture, Krishi Vigyan Kendra, Brahmavar, Udapi \\ University of Agricultural and Horticultural Sciences, Shivamogga
}

*Corresponding author

\begin{tabular}{|c|c|}
\hline & A B S T R A C T \\
\hline & \multirow{4}{*}{$\begin{array}{l}\text { An experiment was carried out at Department of Fruit science, College of Horticulture- } \\
\text { Mudigere, University of Agricultural and Horticultural Sciences, Shivamogga during } \\
2017-18 \text {. The objective of this study was to determine the effect of pre-harvest spray of } \\
\text { nutrients and growth regulators on quality parameters of sapota under hill zone of } \\
\text { Karnataka. This experiment was laid out in randomized complete block design with fifteen } \\
\text { treatments and three replications. The chemicals were sprayed on selected sapota trees at } \\
\text { two intervals i.e. } 1^{\text {st }} \text { spray at } 40 \text { days before the harvest and } 2^{\text {nd }} \text { spray at } 20 \text { days after the } \\
\text { first spray and the harvested fruits were stored in the laboratory at room temperature. The } \\
\text { results revealed that pre-harvest application of CaNO } \mathrm{Can}_{3}(1 \%) \text { or } \mathrm{CaNO}_{3}(1.5 \%) \text { were found } \\
\text { effective for increasing total soluble solids, total sugar, reducing sugar, non-reducing } \\
\text { sugar, ascorbic acid with minimum acidity of sapota fruits. }\end{array}$} \\
\hline $\begin{array}{l}\text { Sapota, Pre-harvest, } \\
\mathrm{CaNO}_{3} \text {, Total } \\
\text { soluble solids }\end{array}$ & \\
\hline Article I & \\
\hline $\begin{array}{l}\text { Accepted: } \\
\text { 12 July } 2019 \\
\text { Available Online: } \\
10 \text { August } 2019\end{array}$ & \\
\hline
\end{tabular}

\section{Introduction}

Sapota (Manilkara achras Mill.) is tropical fruit, belongs to the family sapotaceae. It is popularly known by several names such as chiku in India, sapodilla, zapota or sapodilla plum in different regions of the world. It is native to Mexico and tropical America. India is considered to be the largest producer of sapota in the world and it is mainly cultivated for its delicious fruits. In India, the major sapota growing states are Maharashtra,
Gujarat, Karnataka, Tamil Nadu, Andra Pradesh, West Bengal, Uttar Pradesh, Punjab and Haryana. Among all the states, Karnataka is the leading sapota producing state and contributes to about 26.5 per cent of the total production in the country (NHB 2016-17). Sapota is a climacteric fruit and exhibits a sudden rise in respiration after harvest (Chundawat, 1998). The shelf life of the sapota fruit deteriorates as soon as the climacteric peak is reached. 
Plant growth regulators as pre-harvest treatments have proved to be a useful tool in delaying fruit ripening. Auxins, gibberellins and cytokinins are independently or in combination are known to resist the fruit senescence by interfering the action of ethylene production during ripening (Sacher, 1973). Among various plant nutrients, calcium has its desirable effect in delaying ripening and senescence, increase in firmness, vitamin $\mathrm{C}$ and phenolic contents. Potassium has also received considerable attention due to enhanced production of protein, thus it improves the efficiency of nitrogenous fertilizer and increases the ability of plants to withstand stress condition. Boron is another chemical nutrient which plays major role in cell division, cell wall strengthening and development, fruit and seed development. Hence adequate boron nutrition is critical for getting high yield and quality of sapota. Therefore the present investigation was carried out to assess the response of preharvest spray of chemicals and plant growth regulators on quality attributes of sapota.

\section{Materials and Methods}

The present investigation was carried out at sapota orchard, College of Horticulture Mudigere, Chikamagalur during 2017-18. The experiment was laid out in randomized complete block design with three replications and fifteen treatments. The uniform sized sapota trees were marked and sprayed with different nutrients and plant growth regulators viz., $\mathrm{T}_{1}-$ control, $\mathrm{T}_{2}-\mathrm{GA}_{3}$ 200ppm, $\mathrm{T}_{3}-\mathrm{GA}_{3}$ 300ppm, $\mathrm{T}_{4^{-}}$Kinetin 50ppm, $\mathrm{T}_{5^{-}}$Kinetin 100ppm, $\mathrm{T}_{6^{-}}$2,4-D 10ppm, $\mathrm{T}_{7^{-}}$2,4-D 20ppm, $\mathrm{T}_{8^{-}}$Boron 0.2\%, $\mathrm{T}_{9^{-}}$Boron 0.4\%, $\mathrm{T}_{10^{-}} \mathrm{CaCl}_{2}$ $1 \%, \mathrm{~T}_{11^{-}} \mathrm{CaCl}_{2} 1.5 \%, \mathrm{~T}_{12^{-}} \mathrm{Ca}\left(\mathrm{NO}_{3}\right)_{2} 1 \%, \mathrm{~T}_{13^{-}}$ $\mathrm{Ca}\left(\mathrm{NO}_{3}\right)_{2} 1.5 \%, \mathrm{~T}_{14}-\mathrm{KCl}_{2} 0.5 \%$ and $\mathrm{T}_{15}-\mathrm{KCl}_{2}$ $1 \%$ at two intervals i.e 40 days before harvest and 20 days after $1^{\text {st }}$ spray. The fruits were harvested when colour of the fruit turned to light brown i.e potato colour. The harvested fruits were brought to the laboratory and two kilograms of sapota fruits for each treatment were kept for observation at room temperature in the laboratory. The fruits were assessed at $3^{\text {rd }}, 6^{\text {th }}, 9^{\text {th }}$ and $12^{\text {th }}$ day of storage for TSS, acidity, total sugar, reducing sugar, non-reducing sugar and ascorbic acid.

\section{Results and Discussion}

Total soluble solids (Table 1) increased initially up to $9^{\text {th }}$ day of storage period in all the treatments and later on declined up to end of storage. The maximum TSS (19.67, 21.33, 24.97 and $23.81{ }^{\circ}$ Brix) was recorded by treatment $\mathrm{T}_{12}\left(\mathrm{CaNO}_{3} @ 1 \%\right)$ which was on par with treatment $\mathrm{T}_{13}\left(\mathrm{CaNO}_{3} @ 1.5 \%\right)$ i.e. 19.63, 20.97, 24.93 and 23.67 ${ }^{\circ}$ Brix, respectively at $3^{\text {rd }}, 6^{\text {th }}, 9^{\text {th }}$ and $12^{\text {th }}$ day of storage period. At $9^{\text {th }}$ day onwards control fruits showed more shriveling and loss of appearance hence fruits were discarded.

The increase in TSS during initial storage period might be due to hydrolysis of starch into sugar on complete hydrolysis of starch no further increases occur and subsequently decline in TSS is predictable. Similar findings have been reported by Jawandha et al., (2007) and Yadav et al., (2009) in ber, Rajput et al., (2008) in guava, Ramezanian et al., (2009) in pomegranate, Bhalerao et al., (2010) in sapota, Karemera and Habimana (2014) in mango and Kirmani et al., (2015) in Plum.

Data on titratable acidity showed nonsignificant differences among all the treatments of sapota fruit under ambient condition (Table 1). Nevertheless, acidity showed decrease during the storage period, the decline in acidity might be due to the conversion of acid into sugar. The similar result on acidity was also reported by Gupta et al., (1987) in ber, Jayachandran et al., (2005) in guava and Bhalerao et al., (2010) in sapota. 
The present investigation exhibited a continuous decline in the ascorbic acid content of fruit with the increased storage duration. Data (Table 2) on ascorbic acid revealed that under ambient condition, the highest ascorbic acid (23.86, 19.11, 15.38 and $9.64 \mathrm{mg} / 100 \mathrm{~g}$ pulp) at $3^{\text {rd }}, 6^{\text {th }}, 9^{\text {th }}$ and $12^{\text {th }}$ day of storage period, respectively was recorded in treatment $\mathrm{T}_{12}\left(\mathrm{CaNO}_{3} @ 1 \%\right)$ which, remained at par with treatment $\mathrm{T}_{13}$
$\left(\mathrm{CaNO}_{3} @ 1.5 \%\right)$ i.e. $23.85,19.07,13.50$ and $9.61 \mathrm{mg} / 100 \mathrm{~g}$ pulp at $3^{\text {rd }}, 6^{\text {th }}, 9^{\text {th }}$ and $12^{\text {th }}$ day of storage period, respectively.

The gradual reduction in ascorbic acid content during entire storage period might be due to its degradation through enzymatic oxidation of L-ascorbic acid to dehydro ascorbic acid during metabolic processes.

Table.1 Effect of pre-harvest foliar application of nutrients and plant growth regulators on Total soluble solids and Titratable acidity of sapota at different days after harvest

\begin{tabular}{|c|c|c|c|c|c|c|c|c|}
\hline \multirow{2}{*}{ Treatments } & \multicolumn{4}{|c|}{ Total soluble solids ( ${ }^{0}$ Brix) } & \multicolumn{3}{|c|}{ Titratable acidity (\%) } & \multirow[b]{2}{*}{$12^{\text {th }}$ day } \\
\hline & $3^{\text {rd }}$ day & $6^{\text {th }}$ day & $9^{\text {th }}$ day & $12^{\text {th }}$ day & $3^{\text {rd }}$ day & $6^{\text {th }}$ day & $9^{\text {th }}$ day & \\
\hline $\mathbf{T}_{1^{-}}$Control & 16.57 & 18.17 & 22.10 & -- & 0.24 & 0.19 & 0.14 & -- \\
\hline$T_{2^{-}}-G_{3}$ at $200 \mathrm{ppm}$ & 18.27 & 19.93 & 23.47 & 21.24 & 0.19 & 0.16 & 0.11 & 0.08 \\
\hline $\mathbf{T}_{3^{-}}-\mathbf{G A}_{3}$ at $300 \mathrm{ppm}$ & 17.93 & 19.70 & 23.30 & 20.32 & 0.14 & 0.16 & 0.11 & 0.08 \\
\hline$T_{4}-$ Kinetin at 50 ppm & 17.73 & 19.43 & 22.73 & 20.23 & 0.21 & 0.19 & 0.13 & 0.06 \\
\hline $\begin{array}{l}T_{5}-\text { Kinetin at } 100 \\
\text { ppm }\end{array}$ & 16.83 & 19.40 & 22.40 & 19.25 & 0.21 & 0.19 & 0.13 & 0.08 \\
\hline$T_{6}-2,4-D$ at $10 \mathrm{ppm}$ & 18.63 & 20.03 & 24.03 & -- & 0.19 & 0.14 & 0.11 & -- \\
\hline$T_{7-}-2,4-D$ at $20 \mathrm{ppm}$ & 18.53 & 20.00 & 23.87 & -- & 0.19 & 0.16 & 0.11 & -- \\
\hline $\mathrm{T}_{8}$ - Boron at $\mathbf{0 . 2 \%}$ & 19.13 & 20.63 & 24.27 & -- & 0.16 & 0.13 & 0.08 & -- \\
\hline $\mathrm{T}_{9}$ - Boron at $\mathbf{0 . 4 \%}$ & 18.83 & 20.40 & 24.26 & -- & 0.16 & 0.13 & 0.08 & -- \\
\hline $\mathrm{T}_{10^{-}} \mathrm{CaCl}_{2}$ at $1 \%$ & 19.47 & 20.67 & 24.77 & 23.53 & 0.14 & 0.11 & 0.08 & 0.05 \\
\hline $\mathrm{T}_{11-} \mathrm{CaCl}_{2}$ at $1.5 \%$ & 19.37 & 20.65 & 24.30 & 22.87 & 0.16 & 0.11 & 0.08 & 0.05 \\
\hline $\mathrm{T}_{12}-\mathrm{CaNO}_{3}$ at $1 \%$ & 19.67 & 21.33 & 24.97 & 23.81 & 0.13 & 0.11 & 0.08 & 0.05 \\
\hline $\mathrm{T}_{13}-\mathrm{CaNO}_{3}$ at $1.5 \%$ & 19.63 & 20.97 & 24.93 & 23.67 & 0.14 & 0.11 & 0.08 & 0.05 \\
\hline $\mathrm{T}_{14-}-\mathrm{KCl}_{2}$ at $0.5 \%$ & 18.77 & 20.30 & 23.93 & -- & 0.16 & 0.13 & 0.11 & -- \\
\hline $\mathrm{T}_{15^{-}} \mathrm{KCl}_{2}$ at $1 \%$ & 18.70 & 20.17 & 23.97 & -- & 0.19 & 0.14 & 0.12 & -- \\
\hline S.Em \pm & 0.57 & 0.43 & 0.09 & 0.30 & 0.00 & 0.01 & 0.01 & 0.00 \\
\hline C.D at $1 \%$ & 2.23 & 1.69 & 0.34 & 1.19 & NS & NS & NS & NS \\
\hline
\end{tabular}

Note: -- Termination of shelf life 
Table.2 Effect of pre-harvest foliar application of nutrients and plant growth regulators on Ascorbic acid and Total sugar content of sapota at different days after harvest

\begin{tabular}{|c|c|c|c|c|c|c|c|c|}
\hline \multirow{2}{*}{ Treatments } & \multicolumn{4}{|c|}{ Ascorbic acid (mg/100g pulp) } & \multicolumn{4}{|c|}{ Total sugar $(\%)$} \\
\hline & $3^{\text {rd }}$ day & $6^{\text {th }}$ day & $9^{\text {th }}$ day & $12^{\text {th }}$ day & $3^{\text {rd }}$ day & $6^{\text {th }}$ day & $9^{\text {th }}$ day & $\begin{array}{l}12^{\text {th }} \\
\text { day }\end{array}$ \\
\hline $\mathbf{T}_{1^{-}}$Control & 14.20 & 12.60 & 09.38 & -- & 11.46 & 14.92 & 18.05 & -- \\
\hline$T_{2^{-}}-\mathrm{GA}_{3}$ at $200 \mathrm{ppm}$ & 19.03 & 16.53 & 10.83 & 9.48 & 15.11 & 16.97 & 21.84 & 19.76 \\
\hline$T_{3^{-}}-\mathrm{GA}_{3}$ at $300 \mathrm{ppm}$ & 19.02 & 16.51 & 10.76 & 9.44 & 13.87 & 16.63 & 21.58 & 19.45 \\
\hline$T_{4}$ - Kinetin at 50 ppm & 14.51 & 13.31 & 10.64 & 7.25 & 13.21 & 16.19 & 21.25 & 17.76 \\
\hline $\begin{array}{l}\mathbf{T}_{5}-\text { Kinetin at } 100 \\
\text { ppm }\end{array}$ & 14.26 & 12.77 & 10.56 & 6.14 & 12.89 & 15.79 & 20.91 & 16.93 \\
\hline $\mathrm{T}_{6}-2,4-\mathrm{D}$ at $10 \mathrm{ppm}$ & 19.06 & 17.13 & 10.90 & -- & 15.40 & 17.86 & 22.51 & -- \\
\hline$T_{7^{-}}-2,4-\mathrm{D}$ at $20 \mathrm{ppm}$ & 19.04 & 16.81 & 10.88 & -- & 14.95 & 17.23 & 22.39 & -- \\
\hline $\mathbf{T}_{8}$ - Boron at $0.2 \%$ & 19.13 & 17.89 & 12.51 & -- & 16.89 & 19.35 & 22.93 & -- \\
\hline $\mathbf{T}_{9-}$ Boron at $0.4 \%$ & 19.12 & 17.74 & 11.55 & -- & 16.55 & 18.55 & 22.87 & -- \\
\hline $\mathrm{T}_{10^{-}} \mathrm{CaCl}_{2}$ at $1 \%$ & 23.78 & 18.83 & 12.87 & 9.57 & 18.34 & 19.93 & 23.31 & 22.40 \\
\hline $\mathrm{T}_{11^{-}} \mathrm{CaCl}_{2}$ at $1.5 \%$ & 19.14 & 18.26 & 12.75 & 9.56 & 17.93 & 19.77 & 23.25 & 22.09 \\
\hline $\mathrm{T}_{12-} \mathrm{CaNO}_{3}$ at $1 \%$ & 23.86 & 19.11 & 15.38 & 9.64 & 20.06 & 21.16 & 23.65 & 22.42 \\
\hline $\mathrm{T}_{13^{-}} \mathrm{CaNO}_{3}$ at $1.5 \%$ & 23.85 & 19.07 & 13.50 & 9.61 & 19.25 & 20.09 & 23.50 & 21.75 \\
\hline $\mathrm{T}_{14^{-}} \mathrm{KCl}_{2}$ at $0.5 \%$ & 19.12 & 17.72 & 11.23 & -- & 16.15 & 18.03 & 22.64 & -- \\
\hline $\mathrm{T}_{15^{-}} \mathrm{KCl}_{2}$ at $1 \%$ & 19.06 & 17.59 & 11.11 & -- & 15.49 & 18.01 & 22.57 & -- \\
\hline S.Em \pm & 0.06 & 0.13 & 0.17 & 0.24 & 0.64 & 0.57 & 0.64 & 0.50 \\
\hline C.D at $1 \%$ & 0.22 & 0.51 & 0.67 & 0.93 & 2.52 & 2.27 & 2.51 & 1.95 \\
\hline
\end{tabular}

Note: -- Termination of shelf life 
Int.J.Curr.Microbiol.App.Sci (2019) 8(8): 1547-1553

Table.3 Effect of pre-harvest foliar application of nutrients and plant growth regulators on Reducing sugar and Non-reducing sugar content of sapota at different days after harvest

\begin{tabular}{|c|c|c|c|c|c|c|c|c|}
\hline \multirow{2}{*}{ Treatments } & \multicolumn{4}{|c|}{ Reducing sugar (\%) } & \multicolumn{4}{|c|}{ Non-reducing sugar (\%) } \\
\hline & $3^{\text {rd }}$ day & $6^{\text {th }}$ day & $9^{\text {th }}$ day & $12^{\text {th }}$ day & $3^{\text {rd day }}$ & $6^{\text {th }}$ day & $9^{\text {th }}$ day & $\begin{array}{l}12^{\text {th }} \\
\text { day }\end{array}$ \\
\hline $\mathbf{T}_{1}$ - Control & 05.49 & 08.07 & 09.06 & -- & 5.97 & 6.85 & 8.99 & -- \\
\hline$T_{2^{-}}-\mathrm{GA}_{3}$ at $200 \mathrm{ppm}$ & 07.98 & 09.78 & 12.58 & 11.51 & 7.13 & 7.19 & 9.26 & 8.25 \\
\hline$T_{3}-G_{3}$ at 300 ppm & 07.60 & 09.37 & 12.25 & 11.25 & 6.27 & 7.26 & 9.33 & 8.20 \\
\hline$T_{4}-$ Kinetin at $50 \mathrm{ppm}$ & 06.84 & 08.63 & 12.17 & 09.64 & 6.37 & 7.56 & 9.08 & 8.12 \\
\hline $\begin{array}{l}T_{5}-\text { Kinetin at } 100 \\
\text { ppm }\end{array}$ & 06.77 & 08.60 & 11.56 & 09.57 & 6.12 & 7.19 & 9.35 & 7.36 \\
\hline$T_{6-2}-4-D$ at $10 \mathrm{ppm}$ & 08.20 & 10.07 & 13.04 & -- & 7.2 & 7.79 & 9.47 & -- \\
\hline$T_{7}-2,4-D$ at $20 \mathrm{ppm}$ & 08.18 & 10.01 & 12.60 & -- & 6.77 & 7.22 & 9.79 & -- \\
\hline $\mathrm{T}_{8}$ - Boron at $0.2 \%$ & 09.74 & 11.26 & 13.35 & -- & 7.15 & 8.09 & 9.58 & -- \\
\hline $\mathrm{T}_{9}$ - Boron at $0.4 \%$ & 09.56 & 11.18 & 13.16 & -- & 6.99 & 7.37 & 9.71 & -- \\
\hline $\mathrm{T}_{10^{-}} \mathrm{CaCl}_{2}$ at $1 \%$ & 10.72 & 11.41 & 13.46 & 12.47 & 7.62 & 8.52 & 9.85 & 9.93 \\
\hline $\mathrm{T}_{11}-\mathrm{CaCl}_{2}$ at $1.5 \%$ & 10.19 & 11.29 & 13.44 & 12.45 & 7.74 & 8.48 & 9.81 & 9.64 \\
\hline $\mathrm{T}_{12^{-}} \mathrm{CaNO}_{3}$ at $1 \%$ & 11.73 & 12.51 & 13.72 & 12.90 & 8.33 & 8.65 & 9.93 & 9.52 \\
\hline $\mathrm{T}_{13^{-}} \mathrm{CaNO}_{3}$ at $1.5 \%$ & 11.08 & 11.47 & 13.63 & 12.51 & 8.17 & 8.62 & 9.87 & 9.24 \\
\hline $\mathrm{T}_{14-} \mathrm{KCl}_{2}$ at $0.5 \%$ & 08.89 & 10.81 & 13.14 & -- & 7.26 & 7.22 & 9.50 & -- \\
\hline $\mathrm{T}_{15}-\mathrm{KCl}_{2}$ at $1 \%$ & 08.80 & 10.38 & 13.12 & -- & 6.69 & 7.63 & 9.45 & -- \\
\hline S.Em \pm & 0.52 & 0.46 & 0.44 & 0.36 & 0.08 & 0.03 & 0.03 & 0.03 \\
\hline C.D at $1 \%$ & 2.05 & 1.81 & 1.73 & 1.41 & 0.33 & 0.10 & 0.11 & 0.10 \\
\hline
\end{tabular}

Note: -- Termination of shelf life

Similar observations was also recorded by Jawandha et al., (2007) and Yadav et al., (2009) in ber, Rajput et al., (2008) and Bisen et al., (2014) in guava, Ramezanian et al., (2009) in pomegranate, Lal et al., (2011) in apricot and Kirmani et al., (2015) in Plum.

Total sugar (Table 2) content of sapota fruit at different stages of ripening increased significantly from mature to ripe stage with as slight decline at overripe stage. In ambient storage the total sugar increase up to $9^{\text {th }}$ day of storage period and then after it started declining. The maximum total sugar (20.06, 21.16, 23.65 and $22.42 \%$ ) was observed in treatment $\mathrm{T}_{12}\left(\mathrm{CaNO}_{3} @ 1 \%\right)$ at $3^{\text {rd }}, 6^{\text {th }}, 9^{\text {th }}$ and $12^{\text {th }}$ day of storage period, respectively which, remained at par with treatment $T_{13}$ 
$\left(\mathrm{CaNO}_{3} @ 1.5 \%\right)$ i.e. 19.25, 20.09, 23.5 and $21.75 \%$ at $3^{\text {rd }}, 6^{\text {th }}, 9^{\text {th }}$ and $12^{\text {th }}$ day of storage period, respectively.

The increase in total sugar during initial storage period might be due to hydrolysis of starch into sugar as on complete hydrolysis of starch no further increase occurs and subsequently a decline in total sugar is predictable. The present investigation is in conformity with the results reported by, Rajkumar et al., (2006) in papaya, Yadav et al., (2009) in ber, Bhalerao et al., (2010) in sapota, Lal et al., (2011) in apricot, Alila and Achumi (2012) in litchi, Karemera and Habimana (2014) in mango, Bisen et al., (2014) in guava and Kirmani et al., (2015) in Plum.

Accumulation of reducing sugar was gradually increased with a slight decline at the end of storage period in ambient condition (Table 3). The maximum reducing sugar $(11.73,12.51,13.72$ and $12.90 \%)$ was observed in treatment $\mathrm{T}_{12}\left(\mathrm{CaNO}_{3} @ 1 \%\right)$ at $3^{\text {rd }}, 6^{\text {th }}, 9^{\text {th }}$ and $12^{\text {th }}$ day of storage period respectively, followed by treatment $\mathrm{T}_{13}$ $\left(\mathrm{CaNO}_{3} @ 1.5 \%\right)$ i.e. $11.08,11.47,13.63$ and $12.51 \%$ at $3^{\text {rd }}, 6^{\text {th }}, 9^{\text {th }}$ and $12^{\text {th }}$ day of ambient storage period, respectively. The increase of reducing sugar content by calcium application might be due to the less utilization of sugar during respiration and conversion of starch in to sugar, while the subsequent decline was perhaps due to consumption of sugar for respiration during storage. The present investigation is in conformity with the results reported by Yadav et al., (2009) in ber, Bhalerao et al., (2010) in sapota, Alila and Achumi (2012) in litchi, Bisen et al., (2014) in guava and Kirmani et al., (2015) in Plum.

Significant difference was observed among all the treatments with respect to non-reducing sugar. Under ambient storage, highest nonreducing sugar $(8.33,8.65,9.93$ and $9.52 \%)$ at $3^{\text {rd }}, 6^{\text {th }}, 9^{\text {th }}$ and $12^{\text {th }}$ day of storage period, respectively was found in treatment $\mathrm{T}_{12}$ $\left(\mathrm{CaNO}_{3} @ 1 \%\right)$ which, remained at par with treatment $\mathrm{T}_{13}\left(\mathrm{CaNO}_{3} @ 1.5 \%\right)$ i.e. 8.17, $8.62,9.87$ and $9.24 \%$, respectively (Table 3).

The increase in non-reducing sugar during storage was due to the conversion of starch into sugar, while, the subsequent decrease in sugar was might be due to consumption of sugar for respiration during storage period. These results are in accordance with the findings of Bhalerao et al., (2010) in sapota, Alila and Achumi (2012) in litchi, Bisen et al., (2014) in guava, Karemera and Habimana (2014) in mango and Kirmani et al., (2015) in plum.

The present study clearly indicated that preharvest spraying of $\mathrm{CaNO}_{3}$ at $(1 \%)$ or $\mathrm{CaNO}_{3}$ at $(1.5 \%)$ is effective and found promising for maintaining quality attributes viz. TSS, acidity, total sugar, reducing sugar, nonreducing sugar and ascorbic acid under ambient storage.

\section{References}

Alila, P. and Achumi, I. 2012. Pre-harvest chemical treatments affect post-harvest quality of litchi fruit. Acta Horti, 9 (12):34-37.

Bhalerao, R. R., Parmar, B. R., Padhiar, B. V. and Bhalerao, P. P. 2010. Pre-harvest spray of different sources of calcium to improve the bio chemical qualities of sapota fruits [Manilkara achras (Mill) Fosberg] cv. Kalipatti. Asian j. Horti, 5(1):93-95.

Bisen, S., Thakur, R. S. and Tembhare, D. 2014. Effect of calcium nitrate and gibberellic acid application on growth, fruit quality and post-harvest behavior of guava fruit cv. Allahabad Safeda. Int. J. Enviro. Sci, 5: 55-62.

Chundawat, B. S. 1998. Sapota. Agrotech 
Publishing Academy, Udaiput, India. Gupta, O. P., Siddiqui, S. and Chauhan, K. S. 1987. Evaluation of various calcium compounds for increasing the shelf life of ber cv. Umaran. Indian J. Horti, 62 (1): $68-70$.

Jawandha, S. K., Randhawa, J. S. and Gill, P. P. S. 2007. Effect of different preharvest treatments on the storage of ber cv. Umran. Haryana J. Horti. Sci, 31 (251-254).

Jayachandran, K. S., Srihari, D. and Reddy, Y. N. 2005. Influence of post-harvest calcium treatment on storage quality of Lucknow-49 guavas. CropRes., 28 (1): 60-62.

Karemera, N. J. U. and Habimana, S. 2014. Effect of pre-harvest calcium chloride on post-harvest behavior of mango fruits (Mangifera indica L.) cv. Alphonso. Uni. J. Agri. Res, 2 (3): 119125.

Kirmani, S. N., Mir, M. M., Iqbal, U., Jan, A., Javaid, K., Malik, A. R. and Khan, F. A. 2015. Impact of pre-harvest chemical application on plum (Prunus salicina L.) cv. Santa Rosa quality during storage. Int. Qua. J. Life Sci, 10 (1): 211-215.

Lal, S., Kumar, D., Singh, D., Ahmed, N., Kumar, R. and Dar, G. 2011. Effect of pre-harvest application of calcium chloride and gibberellic acid on shelf- life and post-harvest quality of apricot (Prunus armeniaca L.) cv. Harcot. J. Horti. Sci, 6 (1): 46-51.

NHB Data Base 2016-17 published by National Horticulture Board Department of Agriculture And Cooperation Government of India.

Rajkumar, M., Karuppaiah, P. and Andasamy, R. K. 2006. Effect of calcium on storage behavior, ripening and shelf-life of papaya cv. CO-2 (Carica Papaya L.). Int. J. Agric. Sci, 2 (2): 480-482.

Rajput, B. S., Lekhe, R., Sharma, G. K. and Singh, I. 2008. Effect of pre and postharvest treatments on shelf life and quality of guava fruits (Psidium guajava L.) cv. Gwalior-27.Asian. J. Horti, 3 (2): 368-371.

Ramezanian, A., Rahemi, M. and Vazifehshenas, M. R. 2009. Effect of foliar application of calcium chloride and urea on quantitative and qualitative characteristics of pomegranate fruits. Sci. Horti, 121: 171-175.

Sacher, J. A. 1973. Senescence and postharvest physiology. Ann. Review Pl. Physiol, 24:197-224.

Yadav, I., Sharma, R. K., Goyal, R. K. and Siddiqui, S. 2009. Effect of pre-harvest spray of calcium on the storage of ber (Zizyphus mauritiana L.) cv. Umran. Haryana J. Horti. Sci, 38(3\&4): 243246.

\section{How to cite this article:}

Vani Kumbar, B.S. Shivakumar, M. Ganapathi, Y. Kantharaj and Chaitanya, H.S. 2019. Effect of Pre-harvest Spray of Nutrients and Growth Regulators on Quality Parameters of Sapota under Hill Zone of Karnataka, India. Int.J.Curr.Microbiol.App.Sci. 8(08): 1547-1553. doi: https://doi.org/10.20546/ijcmas.2019.808.182 